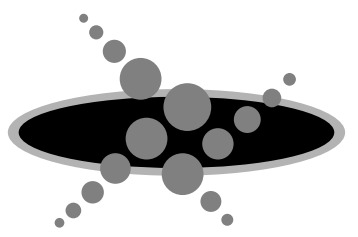

\title{
DNA の高次構造スイッチングと遺伝子発現
}

\author{
名古屋文理短期大学食物栄養学科 吉川祐子 \\ 名古屋大学大学院人間情報学研究科物質 ·生命情報学専攻 湊元幹太 \\ 京都大学大学院理学研究科物理学第一教室, CREST 吉川研一
}

\begin{abstract}
Long DNA molecules above the size of several tens kbp undergo marked discrete transition on their higher-order structure. Recent study on single molecular chain observation indicates that the structural transition of DNA induces discrete ON/OFF switching on transcriptional activity. Changes of environmental parameters induce the morphological variation in folded DNA. We propose a hypothesis that appearance of partially unfolded part on chromatin may concern with the promotion of gene expression.
\end{abstract}

folding transition / DNA condensation / higher-order structure / genetic regulation / phase segregation / transcriptional activity

\section{DNA の凝縮転移と機能}

図 1 は長鎖DNAの“凝縮”に伴う転写活性の变化に ついてのin vitro 実験例である. $\lambda$ ファージDNAの転写 反応活性が, スペルミン (+4価のカチオン) の濃度に 依存して変化するようすを, 図1Aのグラフは示してい る. スペルミンは真核細胞, 原核細胞を問わず, 細胞内に $0.1 \sim 1 \mathrm{mM}$ 程度存在するポリアミンである. スペルミ ンの添加により転写反応はいったん活性化され, 100〜 $200 \mu \mathrm{M}$ 付近で最大活性を示す. 兴の後, 活性はなだらか に低下するが, $400 \mu \mathrm{M}$ を超えると, 転写反応は急激に阻 害されてしまう. 図1Bには, 同樣の反応溶液中 (RNA ポリメラーゼは加えていない)における, RZAPII DNA の蛍光顕微鏡像を示した. スペルミンが $400 \mu \mathrm{M}$ までの 濃度領域では, 個々のDNA 分子は分散した状態である が, $400 \mu \mathrm{M}$ を超えると多分子のDNAが集合した凝集 体が生成する. DNAの劇的な構造変化と転写活性の変 化か溞く相関していることがわかる. 害際の細胞では, DNA とヒストンなどからなるクロマチンの凝縮・脱凝 縮は, 遺伝子活性とどのように関連しているのであろ うか.

常識的には, 図 1での転写抑制にみられるように,

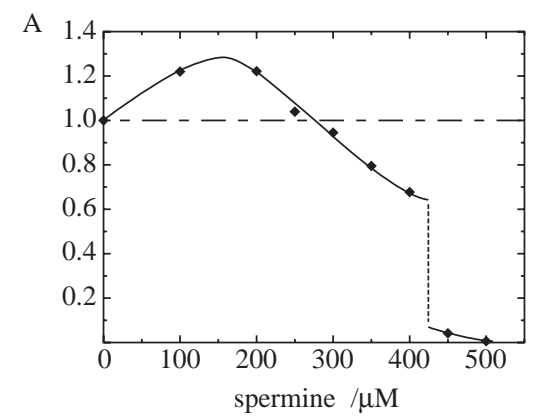

B

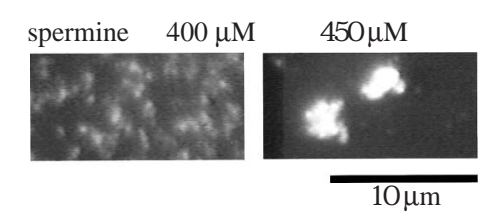

図1転写活性のスイッチング

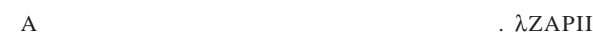
DNA (40 kbp, $\lambda$ ファージDNA を改変したクローニング 用ベクターで, T7プロモータをもつ $\left.{ }^{34)}\right)$ をT7 RNA ポリメ ラーゼにより, $37^{\circ} \mathrm{C} て ゙ 1$ 時間転写した後, 転写産物を蛍光 強度 (RiboGreen) で定量. [spermine] =0 $\mu \mathrm{M}$ における

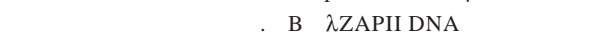
像. 溶液と平衡にあるガラス表面上のDNAを蛍光試薬 DAPI で可視化.

\footnotetext{
Switching of Higher-Order Structure of DNA and Gene Expression

Yuko YOSHIKAWA*, Kanta TSUMOTO** and Kenichi YOSHIKAWA***

* Department of Food and Nutrition, Nagoya Bunri College

** Division of Informatics for Natural Sciences, Graduate School of Human Informatics, Nagoya University

***Department of Physics, Graduate School of Science, Kyoto University; CREST
} 
DNAの“凝縮” (condensation) は, 種々の因子のアク セスを阻害し, 光の読み取りを不活性化するものと予 想できる. しかし, これと対照的に, DNAの“凝縮”が, その活性を増大させるという報告（トポイソメラーゼ 反応 ${ }^{1)}, \lambda$ ファージDNA 自己環化過程 ${ }^{2)}$, 大腸菌RNAポ リメラーゼ反応 ${ }^{3)}$ など） も少なからずある. このように, DNAの“凝縮”と活性の関係についてはいだ不明の 点が多い. 実は, DNAの凝縮転移光のものの理解が, 比 較的最近まで不正確であった ${ }^{4)}$. DNA を含め一般に直鎖 状の高分子において, ランダムコイル状に膨閏した状態 から密に折り畳まれた状態への転移は, 協同的ではある が連続的な変化であり, ON/OFF的なスイッチングとは ならないと従来は考えられていだ)-6).1990 年代半ばに なり, 各々の長鎖DNA( 数 $10 \mathrm{kbp}$ 以上)の凝縮転移は, ランダムコイル状態と折り畳まれた状態との間を, 不連 続に構造変化する 1 次相転移 (ON/OFF 型の転移)であ ることが明らかにされた5)-7). 通常, 気↔液, 液↔固な どにみられる1次相転移では, 系全体がON/OFF型の不 連続転移を示す. 帯れに対し, DNAの場合には, 各々の 分子鎖は不連続転移を起こすが, 多数の分子鎖の集団全 体では,“連続的な転移を示すように見える5).”このた め, in vitro での転写・発現などの実験では, 各々のDNA 分子の不連続性はならされてしまい, 協同的ではある が連続的な変化として観察されてしまうであろう. 光 こで本稿では, 長鎖DNA 分子の構造転移の特性に関す る最近の知見を説明し, 光れを遺伝子活性のスイッチ ング現象とのかかわりて論じたい.

\section{2 . 高次構造の多樣性}

\section{1 構造のスイッチング}

図2の蛍光顕微鏡像は, 全長 $57 \mu \mathrm{m}(166 \mathrm{kbp})$ のT4 フ アージDNAが水溶液中でさまざまな特徵的形態をとる ことを示しているが, これらの構造の間の転移は, いず れも不連続なON/OFFスイッチング5)-10) となる. 図2A はランダムコイルの形態のDNAの蛍光像である. ここ でDNA は, 微視的には太さが $2 \mathrm{~nm}$ の剛直な 2 重らせん であるが, 分子鎖全体にわたって粗視化したときには, ランダムコイル状の構造をとることに注意したい11). このようなコイル状態のDNA 溶液に, 凝縮斉(ポリア ミンなどの多価陽イオン, ポリエチレングリコール (PEG) などの水溶性高分子, セチルトリメチルアンモ ニウムブロミド (CTAB) などの界面活性剂) を加える と, 個々のDNA分子がON/OFF的に転移して凝縮した 状態 (グロビュール)をとるようになる. 図2B はポリア ミン (スペルミン) の添加によって生じた凝縮構造であ る. 観測光の“にじみ効果” のため, 図2B の凝縮体の大

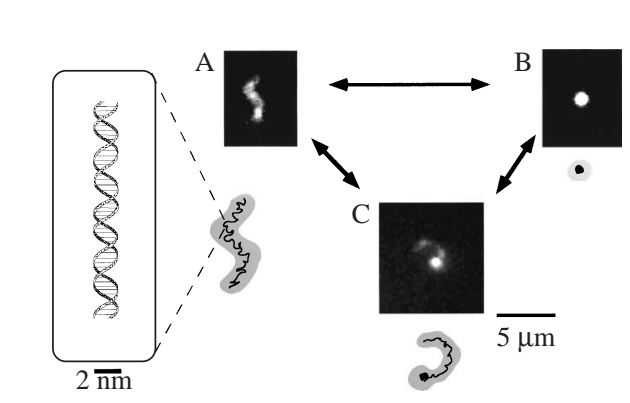

DNAの2重らせん

部分凝縮状態

図2 蛍光顕微鏡観察で観察される単一DNA 分子の高次構造変 化 (T4 DNA, DAPIで染色)

(A) コイル状態. 2 重らせんDNA はミクロには剛直であ るが粗視化するとランダムコイル樣の構造となる. (B) 凝 縮状態 (グロビュール). (C) 部分凝縮状態 (単一分子鎖 内にコイルとグロビュールが共存)，用いた凝縮阂は (B) スペルミジンと $(\mathrm{C})$ スペルミン.

きさは実際よりもかなり大きく見えている. 蛍光顕微鏡 での観察では, 図2Bのようなグロビュールは, コイル状 態のものよりも, より激しい熱運動をしており, そのブ ラウン運動の計測から流体力学的半径は, $50 \sim 100 \mathrm{~nm}$ 程度であることがわかる. これまでの研究から, コイル とグロビュールの間の変化は, $10^{4} \sim 10^{5}$ 倍程度の不連 続な密度変化を伴った 1 次相転移であることが明らか となっている5)-16). 一方, アミノ側鎖を有するポリエチ レングリコール (PEG-A) を作用させたり ${ }^{12)}$, 高塩濃度 条件下でスペルミンやスペルミジン13)を作用させると， コイルからグロビュールへの転移は1段階には起こら ず, 中間的な状態として“部分凝縮構造” か現れる (図 2C). これは単一DNAの分子鎖上で, 折り畳まれた部分 と広がった部分が共存している状態で,「分子鎖内相分 離」状態とみなすことができる. この「分子鎖内相分離 状態は, 準安定状態ではなく平衡構造であることに注意 したい12), 13).

\section{2 折り畳みの形態}

図3には種々の凝縮斉の作用によって生じるDNAの 折り畳み構造の電子顕微鏡像を示した. スペルミジン (+3), スペルミン (+4) やコバルト (+3) などの多 価力チオンを加えて長鎖DNA を凝縮させると, ロッド (図3A) やドーナツ (トロイド) 状 (図3B) の形態を とる ${ }^{11)}$. トロイドとロッドは, ともにDNA 鎖が規則正 しく折り畳まれてできる結晶体であると考えられ, 各々 の出現頻度は凝縮条件に依存して変化する. また図3C に示したように高濃度のスペルミジン添加によりDNA セグメント間の実効的な引力が弱くなる条件下では, 膨潤したトロイドが生成する ${ }^{14)-16)}$. 図3D(は, スペルミ 


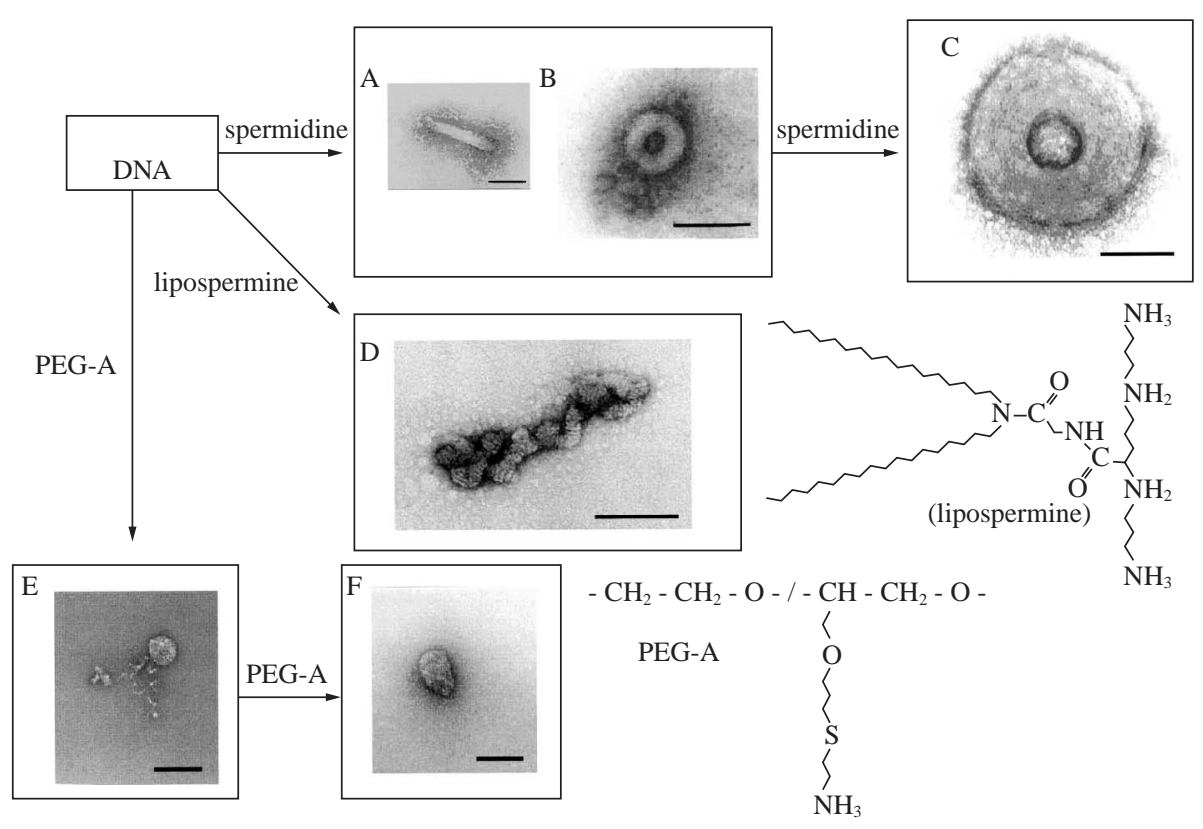

図3種々の凝縮斉の作用によって生じるDNA凝縮構造の透過型電子顕微鏡像

(A) ロッド (B) トロイド (C) 巨大トロイド (D) 系巻き樣 (E) 部分凝縮体 (F) 球状凝縮体.

(A) は入ファージDNA，(B)〜 (F) はT4ファージDNA. スケールバーは $100 \mathrm{~nm}$.

ンを親水性の頭部とするカチオニックリピッドである リポスペルミンとDNA 複合体の構造であり, 高次のら せんをとりながら, 系巻き樣の形態をとっていること がわかる ${ }^{17}$. 図3Eは, PEG-Aによって生じた分子鎖内 相分離体の電子顕微鏡像である ${ }^{12}$. このように凝縮の 条件を制御することにより, 長鎖DNA分子からは多彩 なナノ構造体を創り出すことができる.

図3Dで示したリポスペルミンは遺伝子導入試薬 Transfectam (トランスフェクタム) として市販されて おり, 高い導入効率を示すことか知られている ${ }^{18}$. 溶液 中での蛍光顕微鏡による観察で, DNA・リポスペルミ ン複合体は, 複合体同士が集合してネットワーク構造 を形成することが明らかとなった ${ }^{17)}$. 一方, DNA・ス ペルミン複合体の凝縮高次構造はドーナツ状のトロイ ド構造で, DNA・リポスペルミン複合体に見られるよ うなネットワーク構造を形成せず, スペルミンには遺 伝子導入・発現活性も認められない. このことは, 複合 体の凝縮高次構造をどのように制御するかが, 遺伝子 導入・発現効率を上げるためのキーポイントとなって いることを示唆している17).

\section{3 真珠の首飾り}

図4には, ヒストンH1 (クロマチンを構成する塩基性 タンパク質の1つ)を作用させたときのT4 DNAの蛍光 顕微鏡像を示した ${ }^{19}$. DNA 鎖(こ沿って, 数kbpサイズの
折り畳まれた部分 (ミニグロビュール)か繰り返し現れ， その間をコイル状の構造がつな゙といった，いわゆる

“真珠の首飾り”樣の凝縮構造をとっている ( = pearling) ことがわかる.これは部分凝縮の単位構造が小さくなっ た結果, 単一のDNA 分子に沿って多数のミニグロビュ ールが生じるようになったものと考えられる.この $\mathrm{DNA}$ ・ヒストンH1 複合体は, 塩濃度に依存して光の構 造を著しく変化させる ${ }^{19)}$, 20). 図 4Aの高塩濃度 $(2 \mathrm{M}$ $\mathrm{NaCl})$ 溶液中では, ランダムコイル状のコンホメーショ ンをとっているが, これはDNAからヒストンH1 が解 離していることを示唆している. $0.2 \mathrm{M} \mathrm{NaCl}$ 溶液中で は, 2つのミニグロビュールがコイル状の部分を介して つながっている (図4B) . さらに低塩濃度の $50 \mathrm{mM}$ $\mathrm{NaCl}$ 溶液中では, 伸展した pearling 構造をとっている (図 4C). 低塩濃度条件では, ミニグロビュールがよりコ ンパクトに凝縮しており, イオンの遮蔽効果か弱いため に静電反発か湿著になり, 谷のためにこのように伸展し た構造か観測されるものと考えられる ${ }^{19}$. Huang とCole は, 抽出したクロマチンを用いた実験で,“脱凝縮”して いる部分ではヒストンH1 が少なく,“凝縮”している部 分ではヒストン $\mathrm{H} 1$ が多く分布していることを見出し， 兴の結果を遺伝子活性と関連づけて議論している21). 今後ヒストン H1 か誘起する部分凝縮構造について, 光 の生物的な役割を探ることは意義深いと思われる. 
A
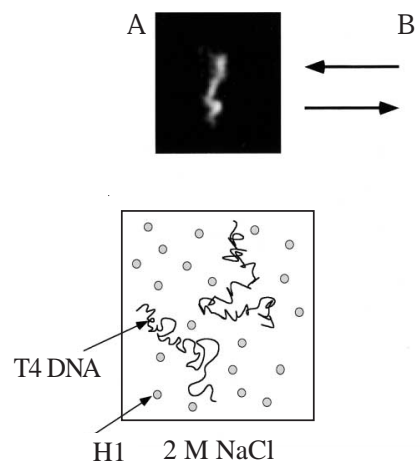

B
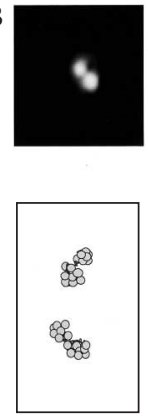

$0.2 \mathrm{M} \mathrm{NaCl}$
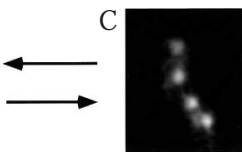

$5 \mu \mathrm{m}$

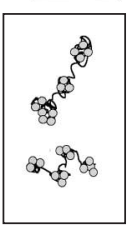

$50 \mathrm{mM} \mathrm{NaCl}$

図4 塩濃度に依存した T4 DNA・ヒストン H1 複合体の高次構造変化

\section{3.多少理屈っぽくなりますが}

\section{1 折り畳み転移: これまでの理論}

高分子鎖を良溶媒から貧溶媒に移すと, $\Theta$ 状態 (理想 鎖に対応する状態)を経て連続的に折り畳み転移が進 行するとの理論は, Flory に始まり, 現代の高分子物理学 の教科書にも引き継がれている. この@状態を経る連 続的な転移は協同的ではあるが, 相転移とは言えない6). 同樣に, 2 重らせんDNAの融解転移, すなわち, ヘリッ クスーコイル転移も相転移ではない, 弚れに対して, 前 節で説明したように, 長鎖 DNAの折り畳み転移は ON/OFF 型の不連続転移であり, 統計物理学における Landau流の定義によると, 1 次相転移に分類される. 長 鎖DNAの折り畳み転移のこのような特徵は, 分子鎖の 堅さ (stiffness) と荷電の効果を考えることにより理解 することができる7)-17).

\section{2 硬い分子鎖力折り畳まれると ${ }^{15), 16)}$}

DNA は高度に荷電した高分子であるので, 水溶液には よく溶ける (良溶媒). 長さが $100 \mathrm{~nm}$ 程度まで (あるい は300 bp以下のサイズ) の2重らせんDNA は, 水中では 剛直な細長い棒のような性質を示す.いま, 高分子がど の程度の長さまて剛直であるのかを表す尺度として持 続長 $l$ (persistent length ; 分子鎖に沿っての角度相関が $1 / e$ になる長さ $; e$ は自然対数の底) をとり, $l の 2$ 倍の長 さ入を単一セグメントの長さ (Kuhn length) とする.す

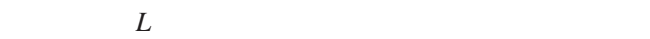
るときのコンホメーションは, 長さが $\lambda(=2 l)$ である $N$ (=L/入) 個のセグメントが, どの方向にも自由に回転で きるジョイントでつながったものとしてモデル化する ことができる ${ }^{6)}$. 2 重らせんDNAでは, $\lambda \approx 100 \mathrm{~nm}$ 程度 であるので, 数 $10 \mathrm{kbp}$ 以上 (長さ $10 \mu \mathrm{m}$ 程度以上) の巨 大な2重らせんDNA分子は水に溶けると, 全体として
はランダムなコイル状の形態をとる (図2 参照). 产の ときのコイル状の分子鎖の広がりを $R_{c}$ とすると, $R_{c} \approx$ $\lambda N^{3 / 5}$ の関係がある6 ${ }^{6}$.一方, DNAがコンパクトに折り畳 まれたときには, 产の体積はセグメントの数 $N$ に比例す るので, セグメントの断面積を $s$ とすると, 折り畳まれ た状態のサイズ $R_{p}$ は, $R_{p} \approx(\lambda s N)^{1 / 3}$ となる. コイル状に広 がった状態と, コンパクトに折り畳まれたときのセグメ

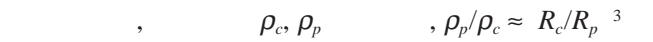
ある. いま, 高分子鎖の硬さを表すパラメータとして $\xi=\lambda^{2} / s$ をとると, $\rho_{p} / \rho_{c} \approx \xi N^{4 / 5}$ となる. これは $N$ が大き くなると, 両方の状態の間で著しい密度の違いが生じる ことを意味している. 2 重らせんDNAの直径は約 $2 \mathrm{~nm}$ であるので, 硬さのパラメータは $\xi \approx 3 \cdot 10^{3}$ 程度である. すると $N=100$ 程度のDNA (30 kbp) では $\rho_{p} / \rho_{c} \sim 10^{5}$, すなわち 10 万倍程度のきわめて大きな密度変化を示す ことになり, 第2節て述べた単一分子鎖観察の結果と対 応する。

\section{3 荷電があると}

不連続転移に与える“荷電” の効果の理論的な詳細 は別の場て論じているので8)-10), 13), 19), 221, 27) ここでは簡 単な考察で光の理論のエッセンスの説明を試みたい. いま, 単一の高分子鎖の自由エネルギー $F$ を密度展開 (ビリアル展開) で表してみよう. $\eta$ セグメントの密 度, $\mu$ を弾性定数とすると,

$$
F \approx \mu\left(\eta^{-2 / 3}+\eta^{2 / 3}\right)+N\left(B \eta+C \eta^{2}+D \eta^{3}\right)
$$

右辺の第 1 項は弾性項, 第 2 項は相互作用項で $B, C, D$ は 弚れ光れ第 2 , 第 3 , 第 4 ビリアル係数であり, 自由エネ ルギーは $k T$ 単位で表している. 負に荷電したセグメ ント同士の相互作用は反発的であるので, 転移領域の 近傍では常に $B>0$ となる. DNA は高度に負に荷電し ているので, 折り畳まれてセグメントが高密度に集合 
するためには, DNA 鎖上のリン酸基が, 対イオンやポリ カチオンと結合を形成することにより, 負荷電は中和 されなければならない221.このようにセグメント密度 が高くなると荷電が中和され, 引力的になるような効 果は, 第 3 , 第 4 ビリアルを $C<0, D>0$ とすることによ り取り入れることができる ${ }^{8)}$. (1) 式で $\eta$ が小さとき には, 弾性項が支配的でありコイル状態洝定となる. $\eta$ が大きくなると第2 項が支配的となり, 高密度に折り 畳まれた状態が安定になる. このように荷電をもつ高 分子は, 密度 (秩序パラメータ) に対して自由エネルギ 一が2つの極小をもつ. 換言すると, 一般に“硬い”荷 電高分子は, ON/OFF 型の 1 次相転移を示す ${ }^{23)}$.

3.4 残留電荷のいたずら

これまでに説明したように, 数 $10 \mathrm{kbp}$ 以上のDNA 分 子は, コイル状態と凝縮状態の2状態間でON/OFF型の 転移をする。凝縮状態には多樣性があり, 光の折り畳み がルーズな場合には, 产の内部に溶媒が侵入する (図2, 図3 参照). すると凝縮体の内部にある電離性の残基か ら対イオンが解離し, 内部がわずかに負に帯電するよ うになる. 静電作用は長距離にわたり働くため, ルーズ な凝縮体はあるサイズ以上では不安定化する. このた めDNA 分子は, 凝縮した部分とコイル部分か共存した 分子内相分離構造をとるようになる. 図4に示したよう な pearling 構造が生成する理由も,このような理論て説 明することが可能である ${ }^{23)}$.

\section{4 . 高次構造と環境との対話 : 仮説}

長いDNA 分子は, コイル状態と凝縮状態との間で, ON/OFFのスイッチングを示すこと,および疑縮状態に は, 固体の結晶のように密に折り畳まれたものと, 液体 的なルーズなものがあることを述べた. このような特 質は, DNA とヒストンの複合体, すなわち長い又クレオ ソームの鎖に対しても成り立つものと考えられる. DNAか秩序正しく, 固く凝縮したときには, 内部の残留 電荷はゼ口となり, 分子鎖全体が安定な構造体を形成 する. 光のため, 遺伝子活性のスイッチはOFFとなる. 実際, 真核細胞ではへテロクロマチンと呼ばれる, 固く 凝縮したドメインがあり,この部位は転写に不活性で あることも知られている24).

弚れに対してルーズに凝縮した場合には, 残留電荷の ために相分離が起こり, 一部分がコイル状にほどけ, 凝 縮相との間で動的な平衡状態が出現する. クロマチン 構造における, ヌクレオソームおよび炎の上位階層の らせんは, 左巻きであるので25), 凝縮相を“足場”にし て, 部分的にほどけて生じたコイル状態には, 2 重らせ んをゆるめる方向へのねじりの応力がかかる ${ }^{26)}$.この
ことは, ほどけているコイル部分では, 谷の遺伝子活性 が大きく上昇することを示唆する.

DNAの高次構造の ON/OFFスイッチングは, 数 10 $\mathrm{kbp}$ から $\mathrm{Mbp}$ 程度の領域について生じるものと考えら れることから, 数 10 から数 100 個の遺伝子を含むDNA 鎖の部分がON/OFFスイッチングをすることになる. そして, 高次構造のスイッチはゲノム上の遺伝子群の 活性にON/OFFの変化を引き起こすであろう. 細胞は ルーズに凝縮した状態を作り出すために, ヒストンの アセチル化などを利用したり，ヒストン $\mathrm{H} 1$ タンパク質 の量をコントロールしているのではないだろうか. 上 記の仮説で重要なことは, DNAの高次構造のスイッチ ングは, 無機イオン ${ }^{27)}$, ポリアミン ${ }^{10), 13)}$, 水溶性高分子 の PEG $^{91}$ (混杂佼力果) や, ATP ${ }^{28)}, \mathrm{RNA}^{29)}$ などの, DNAに 対して非特異的な作用をする分子やイオンによっても 引き起こされるということである. すなわち分化など に伴う細胞内外環境の変化が, DNAの高次構造をスイ ッチし, 兴の結果, 一群の遺伝子群をON/OFFすること ができる. 生きた細胞では, このような非特異的な制御 のメカニズムと, 個々の遺伝子に対する特異的な相互 作用の機構 (鍵と鍵穴の関係) が, 車の両輪として働い ているものと思われる. 遺伝子活性とDNAの構造相転 移との関係を示唆するものとして, 飢餓状態にある大 腸菌か非酵素的に染色体DNAを相転移させ, ゲノムを 保護するという報告がある ${ }^{30)}$.また, ドーリー(クロー

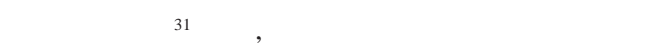
胞の脱分化を利用したことも注目される. 試験管内で の反応とは異なり, 細胞内の微小空間中では, 荷電高分 子と環境とのクロストークの効果か著しくなるものと 予想される ${ }^{32}$, , 33). 細胞内の環境要因によるDNAの高次 構造転移と, 兴の遺伝子機能との関連を解明すること は, 生命科学に残された大きな課題となっている23).

\section{文 献}

1) Krasnow, M. A. and Cozzarelli, N. R. (1982) J. Biol. Chem. 257, 2687-2693.

2) Jary, D. and Sikorav, J. -L. (1999) Biochemistry 38, 3223-3227.

3) Baeza, I., Gariglio, P., Rangel, L. M., Chavez, P., Cervantes, L., Arguello, C., Wong, C. and Montañez, C. (1987) Biochemistry 26, 6387-6392.

4) Bloomfield, V. B. (1996) Curr. Opin. Struct. Biol. 6, 334-341.

5) Yoshikawa, K., Takahashi, M., Vasilevskaya, V. V. and Khokhlov, A. R. (1996) Phys. Rev. Lett. 76, 3029-3031.

6) 吉川研一 (1994) 生命現象と物理学 (北原, 田中編), pp.40-63, 朝倉書店, 東京.

7) Yoshikawa, K. (2001) Adv. Drug Deliv. Rev. 52, 235- 
244.

$8)$ Yoshikawa, K., J. Biol. Phys., in press.

9) Vasilevskaya, V. V., Khokhlov, A. R., Matsuzawa, Y. and Yoshikawa, K. (1995) J. Chem. Phys. 102, 65956602 .

10) Takahashi, M., Yoshikawa, K., Vasilevskaya, V. V. and Khokhlov, A. R. (1997) J. Phys. Chem. B 101, 93969401.

11) Yoshikawa, K. and Yoshikawa, Y. (2002) Pharmaceutical Perspectives of Nucleic Acid-Based Therapy (Mahato, R. I. and Kim, S. W., eds), Taylor \& Francis Group, London, chap.8.

12) Yoshikawa, K., Yoshikawa, Y., Koyama, Y. and Kanbe, T. (1997) J. Am. Chem. Soc. 119, 6473-6477.

13) Takagi, S., Tsumoto, K. and Yoshikawa, K. (2001) J. Chem. Phys. 114, 6942-6949.

14) Yoshikawa, Y., Yoshikawa, K. and Kanbe, T. (1999) Langmuir 15, 4085-4088.

15) Noguchi, H. and Yoshikawa, K. (1997) Chem. Phys. Lett. 278, 184-188.

16) Noguchi, H. and Yoshikawa, K. (1998) J. Chem. Phys. 109, 5070-5077.

17) Yoshikawa, Y., Emi, N., Kanbe, T., Yoshikawa, K. and Saito, H. (1996) FEBS Lett. 396, 71-76.

18) Behr, J. P., Demeneix, B., Loeffler, J. P. and Perez-Mutul, J. (1989) Proc. Natl. Acad. Sci. USA 86, 6982-6986.

19) Yoshikawa, Y., Velichko, Y. S., Ichiba, Y. and Yoshikawa, K. (2001) Eur. J. Biochem. 268, 2593-2599.

20) Yoshikawa, Y., Nomura, S. -i. M., Kanbe, T. and Yoshikawa, K. (2000) Chem. Phys. Lett. 330, 77-82.

21) Huang, H. C. and Cole, R. D. (1984) J. Biol. Chem. 259, 14237-14242.
22) Yamasaki, Y., Teramoto, Y. and Yoshikawa, K. (2001) Biophys. J. 80, 2823-2832.

23 ) 特集, DNA : 紐の物理 (2002) 数理科学6月号, サイ エンス社.

24) A. Wolffe (堀越正美訳) (1997) クロマチン: 染色体 構造と機能, メディカル・サイエンス・インターナシ ヨナル.

25 ) Calladine, C. R. and Drew, H. R. (ワット富士子, 西村善 文訳) (1996) なぜ遺伝子はらせんを巻くのか, 共立出 版, 東京.

26) Sakaue, T., Yoshikawa, K., Yoshimura, S. H. and Takeyasu, K. (2001) Phys. Rev. Lett. 87, 078105.

27) Yamasaki, Y. and Yoshikawa, K. (1997) J. Am. Chem. Soc. 119, 10573-10578.

28) Makita, N. and Yoshikawa, K. (1999) FEBS Lett. 460, 333-337.

29) Tsumoto, K. and Yoshikawa, K. (1999) Biophys. Chem. 82, 1-8.

30) Frenkiel-Krispin, D., Levin-Zaidman, S., Shimoni, E., Wolf, S. G., Wachtel, E. J., Arad, T., Finkel, S. E., Kolter, R. and Minsky, A. (2001) EMBO J. 20, 1184-1191.

31) Wilmut, I., Schnieke, A. E., McWhir, J., Kind, A. J. and Campbell, K. H. (1997) Nature 385, 810-813.

32) Takagi, S. and Yoshikawa, K. (1999) Langmuir 15, 4143-4146.

$33)$ Tsumoto, K., Nomura, S. -i. M., Nakatani, Y. and Yoshikawa, K. (2001) Langmuir 17, 7225-7228.

34) Sambrook, J. and Russell, D. W. (2001) Molecular Cloning, 3rd ed., Cold Spring Harbor Laboratory Press, Cold Spring Harbor, New York, vol.2, chap.11.

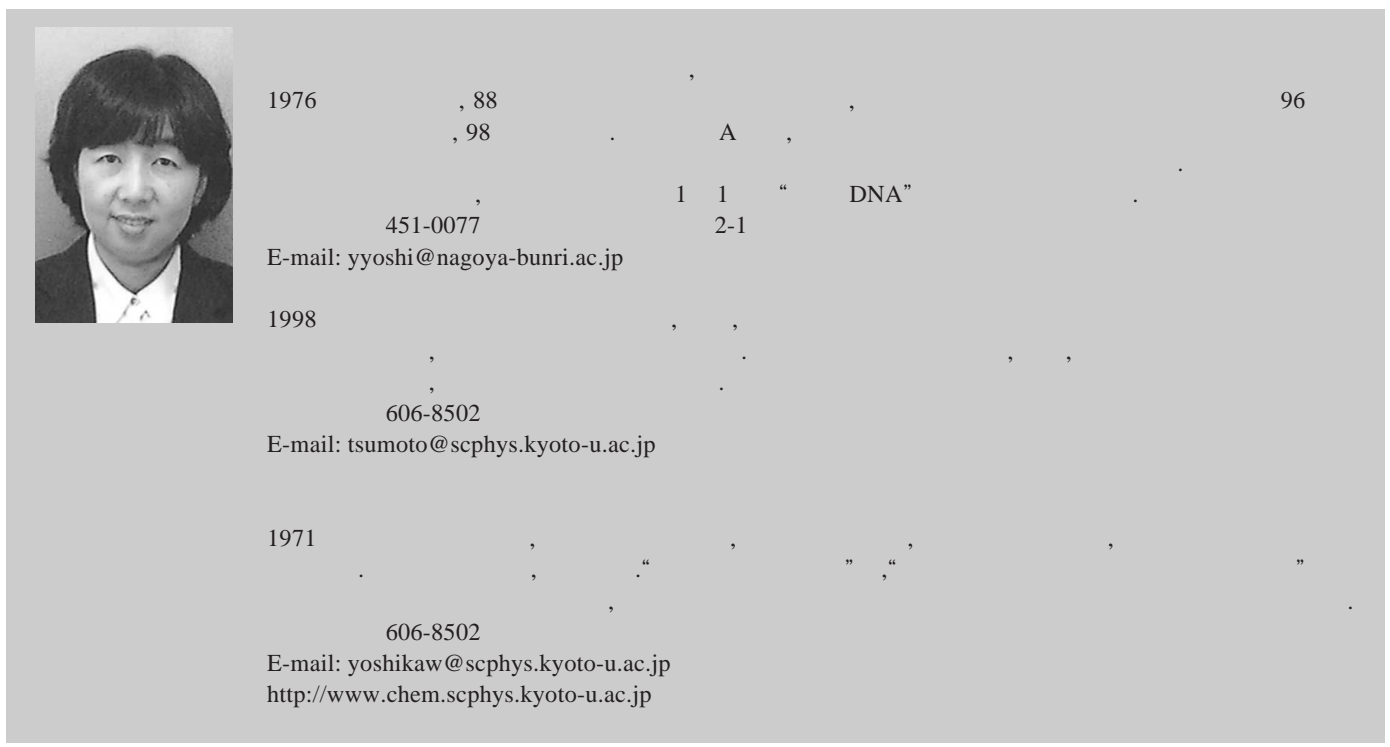

